\title{
The Democratic Eastern Federation and the Poems of Ossian: Egypt
}

\author{
By Kathleen Ann O’Donnell *
}

The founder of the Democratic Eastern Federation and main translator of "The Poems of Ossian", Panayiotis Panas, was born in the British Protectorate of Kephalonia, in the Seven Islands. In 1865, after the uniting of the Seven Island to Greece, Panas went to Alexandria where he published a book of poetry entitled "Memnon" which included an extract from "The Poems of Ossian". This prose poetry, written by the Scottish scholar James Macpherson, contains tales based on Celtic values in the art of combat against usurpation and despotism, led by Ossian and his magnanimous warriors. "Memnon" was circulated to various towns along the Nile including Zagazig, near to where Colonel Ahmad Arabi, a fellah, and leader of the Egyptian revolution, was born. Arabi began the Egyptian revolution after 1878, when the Treaty of Berlin was being discussed by the Great Powers: Egypt was on the agenda. Similar to Panas's colleagues who helped Halim Pasha, Pretender to the throne, under threat from Ismail, to escape from Alexandria in 1866, two residents in Egypt Wilfred Blunt and Lady Augusta Gregory would also give their full support to Arabi in 1882. A fierce opponent of British Imperialism, and firm believer in the liberation of the Egyptian people, Wilfred S. Blunt, a former diplomat and poet, known as the Byron of Egypt - his wife was Byron's granddaughter - believed that Arabi was the best leader to secure Egypt's freedom. Lady Gregory, an Irish scholar and wife of an English diplomat would save Arabi from execution by the English. Both Blunt and Lady Gregory wrote works based on Celtic Mythology translated from the Irish in Ireland, where Blunt was imprisoned by the English in 1888. Was Egypt connected to the Democratic Eastern Federation?

Keywords: 19th Century, Greek translations of Ossian, Democratic Eastern Federation, British Empire in Anatolia.

The Poems of Ossian by James Macpherson are a collection of prose poems based on Celtic mythology, which were first published in the 1760s (Macpherson 1762). They were translated into more than twenty-seven languages (Stafford 1988). Translations of this poetry into Greek were published and distributed with the aim of promoting peaceful unity among different religious groups while, at the same time, exposing the tyranny of Western encroachment on the territory of the Ottoman Empire in the nineteenth century Greek-speaking world.

Almost forty years after the publication of The Poems of Ossian, Thomas Moore, the Irish scholar and close friend of Lord Byron, the AngloScottish Philhellene and poet, wrote an imitation of Ossian against English occupation of Ireland. Moore was one of the first Irishmen to use this version of Celtic mythology to attack British Imperialism. This article was

${ }^{*}$ Researcher, British School at Athens, Greece. 
published in "The Press" in October 1797, one of whose owners was Thomas A. Emmet. It was set up in Dublin by the United Irish after English soldiers had destroyed the newspaper offices of "The Northern Star" in Belfast. Moore's imitation compares English rule of the Irish with its usurpers and corruption to the dignified magnanimity of freedom and justice, which prevailed under their own Fingal and Ossian. It is a call to the Irish to remember their former glory under Ossianic warriors:

"But Britannia commands and Oppression is joined to your fate! Armies are bound to oppose your peace, and their ranks are filled from the land of strangers;

- even your brethren of the soil are against you: ...'O children of Erin! You'r robb'd; why not rouse from your slumber of Death? ... O Erin is condemned in thy senate, and Slavery dwells with thy sons! ... No so was the court of Fingal - not so were the Halls of Selma'" (Clifford 1984).

Because of his young age, Moore was not imprisoned but the conspirator of this radical group whose aim was to "unite Catholic and Protestant nations into one" was hanged, namely Robert Emmet (Clifford 1984). Moore's imitation was republished in "The Celt" published in Dublin and New York (Moore 1857).

In 1814, England gained control of the Seven Islands, a former part of the French Empire, under the Treaty of Paris after the defeat of Napoleon at the Battle of Waterloo as agreed by the allied powers but without the presence of representation of the Seven Islands. In November 1815 the treaty was ratified at the Congress of Vienna. It was to be known as the United States of the Ionian Islands "under the protection of Great Britain". These islands were to enjoy their own constitution, flag and armed forces, "the right to self-government to a portion of the Greek people" (Koukkou 2001). In the summer of 1823, Lord Byron resided on Kephalonia, one of the Seven Islands, before sailing to Messolonghi to meet his demise in his part in the War of Greek Independence in April 1824 (Ravanis 1982). In his collection of poems entitled "Hours of Idleness" published in 1811, Byron, like Moore, also published an adaption of Macpherson's Ossian entitled "Calmar and Orla" based on "Fingal" one of the two epics from The Poems of Ossian. Leader of the Fir Bolg, Calmar and a friend of Cuchullin, was one of the only foes to come to the aid of Fingal in his battle with Swaran the Dane when he began his invasion of Ireland (Macpherson 1996). In a footnote Byron writes that even though he knew of the controversy regarding the authenticity of the poems, he nevertheless believed that their worthiness "remains undisputed". He also added that his attempt in writing an adaptation reveals his proof of how attached he was to The Poems of Ossian (The Works of Lord Byron 1919).

Scholars in the zone chose the myths from The Poems of Ossian not only to uplift their impoverished language (O'Donnell 2014b) but also to instil moral virtues of the highest calibre to expose and combat foreign 
tyranny. One of the first translations of Ossian to reach a wide audience in the area was "Calmar and Orla" by Byron. Byron's adaptation of Ossian was translated into Greek from French. The French translator, Paulin Paris also included notes and commentaries including Byron's memoires published by Thomas Moore. (Paulin Paris 1831) by I. Georgantopoulos and published in the newspaper "Evterpe" in 1850. This journal was circulated throughout the Greek-speaking world including both the Balkans and Anatolia (Georgantopoulos 1850). It was published at a time when England imposed its first blockade on Greece. Failing to inform Russia or France who were part of the three "joint guarantors", after the Greek Revolution, (Thomson 1979) on March 28, 1829 under the London Protocol (Stavrianos 2000), England sent its fleet to blockade Greece. The English wanted the Greek people to reimburse the Portuguese Jew Don Pacificio, a money lender, a resident of Gibraltar and thus an English subject, (Thomson 1979) for damages caused to his property in Athens to the value of 886,736 drachmas and 67 lepta (Philaretos 1897). Byron's translation of Ossian is a call for united justice in Anatolia under threat of gunboat diplomacy by the English. The following extract symbolises that Greeks, who had great respect for Byron, sought justice which is implicit in The Poems of Ossian.

"Children of Morven, said the hero [Fingal], tomorrow we attack the enemy; but where is Cuthullin, the shield of Erin? He rests in the halls of Tura; he knows not where we are. Who will dash through the camp of Lochlin to the hero, and call this valiant chief to arms? .... Mine be the deed', said dark-haired Orla. "And shalt thou fall alone?" said fairhaired Calmar." (Georgantopoulos 1850).

At the same time as publishing "Calmar and Orla", Byron also published his translation of an extract of "Battle Cry", by Rhigas Velestinlis (Pheraios) (Byron 1919). Fearing Western encroachment, Rhigas Velestinlis, the Greek-Wallachian revolutionary scholar, set up a secret organisation in Bucharest, the seat of Greek learning, in 1780, whereby all subjects under Ottoman rule should rise up, including the Egyptians and the Turks themselves, as brothers in unity against tyranny of the Sultan to form self-ruling federations known as the Anatolian Confederation. In this long Patriotic Song there is a call for unity:

"Bulgarians, Albanians, Armenians, Romaics, Arabs and Africans and white people ... Montenegrans.. With one united leap, gird your sword for Freedom against the tyranny of the Ottomans."

He even included the Turkish people oppressed by their own Sultan, (Rhigas Velestinlis 2002).

From 1854-57, the English imposed another blockade on Greece, ostensibly because of the Crimean War (1855-56) but it was mainly because of the insurrections in Thessaly and Epirus. Greeks who volunteered to fight in the uprising in Thessaly included scholars namely the Kephalonian 
Panyiotis Panas, (Stavropoulos 1987) the Epirot Thomas Paschides, (Hatziphotis 1974) the Zakinthian Dimitrius Oikonomopoulos and the leader of the 1862 Cycladic Revolution Nicholas Leotsakos (O'Donnell 2014a). This uprising was put down by the English and French (Korthatos 1956). In 1856, the Kephalonian judge and poet Julius Typaldo published a book of poetry on Zakinthos, which includes two extracts from The Poems of Ossian translated from the Italian by Cesarotti entitled "Two Nights", the first and fourth "Bards" from "Croma". To cement fraternity among the oppressed, Typaldos changes the word "friend" to "brother" in both poems. The book begins with a long Ossianic epic entitled "Rhigas the Inspirer" (Konomos 1953).

The successor to Rhigas Velestinlis and the main Greek translator of The Poems of Ossian was Panayiotis Panas who was born under British Colonial rule in Kephalonia. After suffering torture and imprisonment because of his radical beliefs by the English Protectorate, he left to fight in Thessaly as mentioned above. In March, 1862 there was a Cycladic Revolution in Greece (Stavropoulou 1987). Six months later, Panas published his translation of "Darthula-Lathmon" from the Italian version by Cesarotti, together with copious notes in book form, published in the British Protectorate. After the preface is a dedication to the memory of the three heroes - Leotsakos, Skarvellis and Moraitinis - under which there is a short ode to Orsini, a victim of tyranny. Felice Orsini, an Italian Revolutionary Republican, was guillotined in France in 1858. This is followed by a twenty three lined poem about the three heroes who died in the Cycladic Revolution, recorded as a bloodless coup, comparing them to the sons of Usnoth. The hypothesis connects the story to Temora, extracts of which Panas will translate later. It is noteworthy that although "Dar-thulaLathmon" was published in book form in Kephalonia, all further translations of The Poems of Ossian, published by Panas in Greece, were circulated in newspapers to reach a wider readership in the Greek-speaking world including both "Dar-thula" and "Lathmon" which were republished in 1885 and 1890 respectively (Stavropoulos 1987). The dedication in "Darthula' Lathmon" names the three Republican heroes, the leader of which is Nicholas Leotsakos, who were killed by Greek Royalist soldiers in the Cycladic Revolution. Panas compares them to the sons of Usnoth and cousins of Cuchullin, who were killed by the tyrant Cairbar. In his notes Panas symbolises Cairbar with the tyranny of Western monarchy (Panas 1862).

Out of more than forty prose poems included in The Poems of Ossian why did Panas choose "Dar-thula"? A French version of "Irish Melodies" by Thomas Moore was translated by Louise Swanton Belloc, prefaced by a survey of works by Thomas Moore regarding Irish antiquities and literature by D. O'Sullivan, published in Paris in 1841. This work was available in the National Library, Athens. Swanton Belloc also wrote "Lord Byron". As mentioned above, when "The Death of Calmar and Orla" was translated and published into Greek in 1850 and published in "Evterpe", this adaptation of Ossian by Byron was translated from French into Greek from "The 
Complete Works of Lord Byron including his Memoirs published by Thomas Moore" by M. Paulin Paris in 1830. There is a picture of Thomas Moore with a short note appeared three years later in "Evterpe".

The song "Avenging and Bright", from Moore's "Irish Melodies", becomes "The Vengeance of the Sons of Usnoth" in French. In this poem there is a footnote stating that the song of Deidre is a very ancient Irish myth on which Macpherson based his "Dar-thula". Panas's dedicatory poem can be compared to "Avenging and Bright" in the first two lines:

"Avenging and Bright fall the swift sword of Erin

On him who the brave sons of Usna betray'd....

Revenge on a tyrant. (Swanton Belloc 1841)

In Panas's poem:

'Here the Hellene (in capitals) unsheathes his sword

Fiercely.

The tyrant trembles'". (Panas 1862)

While Moore has "his harp remains silent", Panas writes that songs will be sung once Liberty [in capitals] erects her throne after vengeance has been wrought. This resembles J. W. Lake's sketch of Moore published in Leipsig in 1833:

"When, like a meteor's noxious ray,

The reign of tyranny is o'er: ...

And still is beaming round thy shore

The spirit bright of Liberty,

For thou canst boast a patriot Moore."(Lake 1922)

These examples show a strong connection of Moore's "Irish Melodies" to Panas's dedicatory poem of three Modern Greek heroes compared to the sons of Usnoth. "Dar-thula" was also chosen for its powerful depiction of a cowardly tyrant which is strengthened even more so because Macpherson changes the original Irish myth whereby Deidre commits suicide on top of her lover. Macpherson's interpretation of this Celtic myth, which would rekindle Irish interest in their heroes, was depicted in a painting exhibited in Dublin with great success in the 1850s (Redgrave 1891). The artist Henry Tidey portrays Darthula with an arrow in her side. When Dar-thula fights the tyrant, she dies, wounded by an arrow, with the three sons of Usnoth thus making the tyrant appear even more cowardly by killing a woman. Prevented from beheading Leotsakos, one of the three Republican heroes, the leader of the Greek Catholic King's soldiers, continued firing bullets into his dead body.

The Cycladic Revolution is a vivid example of division among Greek Catholic pro-monarchists and Greek Orthodox anti-monarchists. For example, in 1861, after Aristides Moraitinis was made President of the Supreme Court in Athens, he began his political career after the fall of Othon. His son, Pericles was born in Navpoli in 1837. After studying at the 
Evelpidon School be came an officer. He actively supported his father but was exiled to the Cyclades for his antimonarchial views (Moraitinis 1877). Rescued by Leotsakos, he was one of the three heroes compared to the sons of Usnoth from The Poems of Ossian. Divide and rule was a tool used by British Imperialism in order to weaken the native people so that they could usurp their land. Panas selected certain poems from The Poems of Ossian to serve as an ethical precept for the Democratic Eastern Federation which, like his predecessor, Rhigas, he set up in secret. Under the guise of the Rhigas Association in 1870, the DEA was formed in Athens in 1868; it consisted of about five hundred members who were intellectuals (Stavropoulos 1987). Panas's aim was to unite all people, no matter what faith, based on the first article in Rigas's constitution, so as to create federal states. Based on the influence of Proudhon, (Loukatos 1997: 103-125) Panas encouraged mutualism rather than competition in the zone in the face of Western monarchical encroachment. The teaching of Hellenism including Isocrates, Plato, Chrysostom and the Gospels was to be encouraged to educate the newly freed inhabitants. There is great similarity in the moral ideals of Isocrates and Ossian: be warlike in your knowledge of war and in your own preparations for it, but peaceful in your avoidance of all unjust aggression (Van Hook 1986) and "None ever went sad from Fingal. Oscar! The Lightening of my sword is against the strong in battle; but peaceful it lies by my side when warriors yield in war" (Macpherson 1996). Isocrates defined Hellenes as a title suggesting intelligence, not race, which applied to those sharing Athenian culture (Mathieu 1966). Panas dedicated his first book of poetry to Gerassimus Mavroyiannis (Stavropoulous 1987), a scholar, bard, journalist, historian, artist and art critic, who was a self-exiled Kephalonian living in Athens (Vouna 1966).

Mavroyiannis, translated an extract from Book I from Temora, in his dissertation "On Ossian" in July, 1863, which was published and serialised in Athens in the periodical "Chrysalis" in Athens, during the intermonarchial period when the German Catholic Greek monarch Othon had fled (Mavroyiannis 1863). The civil war is described as the "June events" (Korthatos 1956).

What is interesting is that in Mavroyiannis's dissertation he draws on different sources including the survey by D. O'Sullivan, preceding Belloc's French version of Moore's "Irish Melodies" mentioned above. By describing the comportment of English monarchy towards Bards in Wales, Scotland and Ireland their power is thus manifested, which Greek radicals will use when confronting the present tyranny of Greece, as it was nothing less than a British protectorate. From the rule of Edward 1 in 1284 to Elizabeth 1, Mavoyiannis describes Bards celebrating poetic contests every year, which they called "eisteddford". He retains the Welsh word in Latin script. Even though Ireland was occupied, Bards lasted a long time keeping alive, through their songs, the sacred love of the country in the hearts of the Irish people. Elizabeth the Great ordered the hangings of many minstrels who, by their songs, incited the people to revolt. After the Battle of the Boyne, Bards disappeared completely, and the last Bard of Ireland was 
Turloth O'Carolan who was born in 1670 and died in 1737. His songs were translated into English.

Mavroyiannis's long translation from Cesarotti's version, of "Fingal," whose enemy is the Dane Swaran, was published when Greeks chose a Dane - George Gluxbourg - as the second monarch (Mavroyiannis 1863). Prince Alfred, Queen Victoria's son, was originally selected for this task, but declined the Greek crown (Parmenides 1865). This was also at this time when a third constitution would be ratified the following year, which would take into account the conflict between conservatives and the radical ideas of the people in the Seven Islands that were to be ceded to Modern Greece. Provision was made for "The Start of Working Class Domination". Both translators were striving to clarify the rights of the people and used The Poems of Ossian to support their views (Loukatos 1984).

In 1864, when the Seven Islands united with Greece, Panas stated that the British Protectorate in Corfu had merely moved their administration to Athens with another foreign monarch, after the Bavarian Greek king had abdicated (Stavropoulos 1987). In fact, Greece was described as a Protectorate by the veteran Scot George Finlay, (O'Donnell 2014a) an Athenian resident who had stayed with Byron on Kephalonia in October, 1823 (Ravanis 1982). Finlay befriended Wilfred Scawen Blunt, a young diplomat aged nineteen at the British Embassy, in 1859 (Longford 1979).

In 1865, Panas left Greece for Alexandria (Stavropoulos 1987) where there was turmoil as Ismail the ruler and grandson of Mohamid Ali, the first Viceroy of Egypt of Albanian descent, had endeavoured to buy the primogeniture whereby his son would inherit the throne, by lavishing gifts, at the expense of his people, on the Sultan of the Ottoman Empire; Egypt was its tributary. The pretender to the throne, Halim Pasha, the son of Muhamid Ali and a Bedouin mother, vied for power (Anonymous 1884). Panas set up the newspaper "The Egyptian Eagle" with his classmate Spiro Pherentinos in 1865 (Stavropoulou 1987) who published a long epic dedicated to the erection of the statue of Muhammad Ali (Pherentinos 1872). Interestingly, the Albanian Folklorist and journalist Thimi Mitko emigrated to Alexandria in 1865 also. The ancestors of Muhammad Ali were from Korca, in Albania where Miski was educated. (Elsie 2012). In 1865 , just before the uprising, Panas published a book of poetry entitled "Memnon" with an epigraph to Byron, published by his classmate Ferdinand Oddi of Nile Press, distributed to towns along the Nile (Stavropoulos 1987). The towns included Zagazig, the birthplace of Colonel Ahmad Arabi, a fellah who would rise up as leader of the Egyptian Revolution beginning in 1878 (Blunt 1922) whose views on Republicanism, under a constitution, were very similar to those of the Democratic Eastern Federation. The book "Memnon" includes the poem "Daughter of Lekavitos", first published in Athens in 1861 (Stavropoulou 1987), which is 148 lines long written in blank verse and resembles "Dar-thula" in that Panas uses a similar theme in his personification of the moon:

"Pale face little moon then and like now 
Oh how you shine your shimmering rays,

Suddenly you shelter yourself with discarded cover not to see the ignoble crime". (Memnon 1865)

The book "Memnon" also contains an extract from the epic "Temora" Book IV entitled "The Dream of Cathmor and Sulmala" to portray two brothers: Cairbar, a tyrant, who was mentioned in "Dar-thula" and Cathmor who is regarded as just and greatly respected by Fingal, the father of Ossian. This poem is cryptically used to portray the difference between Ismail, a rapacious tyrant who forces Halim, a just, highly educated prince who was popular with the people, into exile. Halim Pasha, described as "an enlightened ruler" who was commander-in-chief of the army, having received his education at a military academy in Paris. Halim, seemingly, is reported to have taken part at the barricade in 1848 French Revolution (Berman 2004). When Halim had to flee to Istanbul, under threat from Ismail, he was aided by Ferdinand Oddi and Panas's fellow revolutionary fighter of Thessaly in 1856, and the father of Greek-Egyptian journalism and doctor (Nikitaridis 2015) Dionysius Oikonomopoulos (Hatziphotis 1999). Panas returned to Athens in 1866.

At the same time as Panas founded the Democratic Eastern Federation in Athens in 1868, his colleague, the Epirot scholar Paschides also set up this organisation in Bucharest (Todorov 1995). The goal of the DEF was to combat the encroachment of British colonisation under monarchy, by introducing federative states to work under mutualism in the promotion of peace; the teaching of Hellenism was to instil democracy in order to promote harmony among the different people.

Evangelos Zappas, a wealthy Greek veteran born in Albania, who resided permanently in Bucharest, donated a huge sum to the furtherance of Hellenism (New Domi X) through the wisdom of Socrates, the language of Isocrates, Chrysostom and the Gospels (Hadjiphotis 1974). Both Chrysostom (Thomas and Mallett 2011) and Isocrates (Kippis 1781) had been translated into Arabic in the $11^{\text {th }}$ century while the Psalms and the Gospels had been translated into Arabic in the $9^{\text {th }}$ and $10^{\text {th }}$ century (Mozarabs in Cordoba 2002). Early in the 1800s Rigas Velestinlis' "An Anthology of Physics" was translated into Arabic in Damietta to include his well-known maxim "Whoever thinks freely, thinks well" (Hill 2015). In his constitution by Rigas Velestinlis, the first article states that: "Greek democracy does not regard the differences of religion with a hostile eye." Rigas also believed that the law must be first in the ruling of federative states hence the usurping of land or rule by any religious group would be alien to the peaceful aims of the Democratic Eastern Federation. As The Poems of Ossian contains no religion, this poetry was an ideal choice in accommodating unity of the various creeds in the region.

The next translation of The Poems of Ossian by Panas entitled "The Death of Oscar" from "Temora" Book I was published in his own newspaper "Uprising" (Panas 1875), which reported on events in Rumania, an Ottoman tributary, where Panas resided for while. It was published in 
Athens in March, 1875 when the national day of Greece was celebrated and tributes were paid to Rhigas Velestinilis. (Stavropoulou 1987) At this time, there was turmoil in Bosnia-Herzegovina resulting from the visit there by the Austro-Hungarian monarch who ignited dissension among the people in his support of the small minority of Catholics. There were uprisings three months later (Stavrianos 2000). This translation describes how Oscar, son of Ossian, who is supported by Usnoth, the father whose sons were assassinated by Cairbar in "Dar-thula", accompanies Oscar to fight the tyrant. When invited to dine as a guest of Carbair the tyrant attacks Oscar and kills him. Oscar, however, succeeds in killing Cairbar before his own demise (Panas 1875). It symbolises the treachery of Western monarchy in its attempt to conquer the land, namely Hertzeovina, using religion to divide the people.

The following year Panas translated "Oina-morul" in which Ossian forfeits his reward in order to cement peace between former enemies. "Oinamorul" was published in the periodical "Byron" which began publication in 1868, when the DEF was first formed. This poem was published on the same day (February 14, 1876) as a peaceful agreement between all parties, including Midhat Pasha, the Grand Vizier, was reached in a meeting in Constantinople, after the uprising in Herzegovina the previous year, whereby Christian, Jew and Muslim in the zone would live in harmony (Stavrianos 2000). In this poem is a note which implicitly refers to the Democratic Eastern Federation (Panas 1876). In 1875, furthering British Empire interference, Disraeli had obtained the Suez Canal shares via the Rothschilds in Paris sold to the latter by the Khedive Ismail (Bouvier 1967). Disraeli announced in Parliament that the purchasing of these shares would bring peace and security to the zone (Ilion 1876). But Disraeli, the British Prime Minister, objected to the agreement reached in Istanbul under Midhat Pasha, (Seaton Watson 1935) and sent the English fleet, which included Indian Muslims, to the Dardanelles, threatening war (Trevelyan 1944). Both Typaldos and Panas wrote scathing poems entitled "Disraeli". The former suggested that Disraeli be hanged from a fig tree for destroying peace in both the East and the West (Konomos 1953). Panas, who first published "Disraeli-Efendi" in his newspaper "Kikeon" published in Braili in Rumania on 17 September 1876, referred to the English treatment of the Irish and challenged Disraeli regarding peace:

"We leave the willing tiger to bully us,

Having the conviction that it will not delay,

When in the East peace will blossom

Statues will be raised in memory of us, -

of Disraeli and Midhat to always bless them" (Hours of Idleness 1883)

As a result of Disraeli's stance war broke out between Russia and Turkey ending with the signing of the Treaty of San Stefano in March, 1878. Instigated by Disraeli, (Blunt 1922) this treaty was superseded by the Berlin Congress, in July, chaired by Bismarck, the German Chancellor 
(Stavrianos 2000). Two or three months previously a secret agreement had been signed in May with the Sultan, known as the Cyprus Convention whereby Britain obtained Cyprus in return for providing roaming consular services to protect Ottoman Christians in Asia Minor. When this secret Convention was exposed in the London press, the Foreign Office immediately disclaimed any knowledge of its existence. The exposure of this secret Convention almost caused the collapse of the Congress when the French delegate, Waddington, was ready to walk out. The lasting bellicose effects of Bismarck declaring that "there is no Albanian nationality" (Stavrianos 2000), together with his despotic proposal that the French invade Tunis, assured of no objection from the Great Powers, coupled with the French sharing the control with the English of the Egyptian debt, known as the Condominium in order to assuage Waddington's rage (Blunt 1922) still reverberate until today. Egypt thus became a joint European Protectorate under Ottoman jurisdiction.

In 1879, the Sultan replaced Ismail with Halim Pasha. On reading the 1866 Firman on primogeniture it is quite clear that Ismail had not kept his part of the treaty - good administration of Egypt and the development of the well-being of the inhabitants - in the running of Egypt yet Western powers insisted that this Firman be retained so that they could use Tewfick, the son of Ismail, a weak and devious character, as their puppet (Anonymous 1884). Inheriting the family fortune after the death of his eldest brother, Wilfred Scawan Blunt, now a former diplomat and scholar, moved to Cairo with his wife. Married to Lady Anne, scholar and granddaughter of Lord Byron, Blunt saw himself as the supporter of the Egyptian people in their quest for freedom similar to Lord Byron who gave his life to the Greek cause. It was Byron's fervent wish to visit Egypt when he was in Greece but his mother would not support him in this venture (Moore 1835). Blunt became close friends of Colonel Arabi who remarked on what Byron had done for Greece. Arabi agreed with Blunt when the latter quoted Byron "Trust not Freedom to the Frank" (Blunt 1922). It is noteworthy that Panas had included a similar quotation from "Childe Harolde" in a translation he had published in the Telegraph in 1879 (Panas 1879). Both Blunt and his wife were opposed to British Imperialism and Colonialism, especially in its designs on taking control of Egypt. When the Dual Controllers took away the right for all classes to become officers and France invaded Tunisia in August 1881, Arabi set up a revolutionary party (Blunt 1922) based on similar tenets to the Democratic Eastern Federation. Like Panas, Arabi believed in brotherhood, peaceful unity among all creeds and the improvement of the fellah class.

To demonstrate the aspirations of brotherhood among different religions and race, three years after Mitko's founding "The Albanian Bee" a newspaper published in Greek and Albanian in Alexandria, the famous poem "Oh Albania, poor Albania" written by the Albanian scholar and diplomat Pashko Vasa, a Catholic employed as Governor of Beirut from 1882 by the Ottoman Government, was found in Mitko's archives in Alexandria in 1881. Pashko Vasa, influenced by French writers who were 
greatly inspired by The Poems of Ossian including Leopardi and Musset (Van Tieghem 1917), wrote the following:

"Some say 'I believe in God' others 'I in Allah',

Some say 'I am Turk', others 'I am Latin',

Some 'I am Greek, others I am Slav',

But you are brothers, all of you my hapless people!

The priests and the muezzins have deceived you

To divide you and keep you poor." (Elsie 2012)

Two books were published in Athens written by Paschides who advertised them in the periodical "Byron", in 1880 entitled "Muslims, Hebrews and Armenians under Hellenism" and "Wallachians, Bulgarians and Albanians under Hellenism". In 1979, Paschides published "Muslim Albanians (Greek Pelasgians) and Greeks" in which there is a special chapter devoted to Albanian Muslims, translated into Albanian, written in Greek script (Hatdiphotis 1974).

Blunt also befriended the philosopher Muhammid Abdu, the Egyptian scholar and professor at the al-Azhar University in Cairo and follower of Jamal al-Din al-Afghani, the religious leader. He was a reformer of modern Islam. Believing that all three religions of Islam, Judaism and Christianity were complementary rather than in opposition, Muhammad Abdu tried to bring unity of these religions (Elie Kedourie 1997). Further evidence of Muhammed Abdu in this endeavour is found in correspondence which he had with Tolstoy on this subject, which Lady Anne Blunt translated from Arabic into English (Kudelin 2009). "The Gospel according to Tolstoy" was translated into Arabic in 1904 (Encyclopaedia of Arabic Literature 1998). Muhammad Abdu also translated the first three books of Plato's Republic into Arabic, in manuscript, which were auctioned in Sotheby's in 2007 (Liberation 2007). Therefore the propagation of the Democratic Eastern Federation in regard to educating the people through Hellenism was already evident and its precepts continued to be followed even after it disintegrated.

When France invaded Tunis in 1881, it resulted in Arabi realising that in order to protect itself from Western hostility, Egypt must strengthen its ties with the Ottomans (Blunt 1922). This was also the view of Panas who regarded the West as the real danger to freedom under a federal republic (Stavropoulou 1987). The real foes in Egypt were European leading figures, owners of Suez Canal bonds whose financial investment in Egypt was under threat. In order to protect this investment, France and England wanted to invade Egypt; they used the jingoism of "Anti-Islamic crusade" and "in the name of civilisation". At this time the Blunts became friends with the diplomat William Gregory and his young wife, Lady Augusta Gregory an Irish scholar. The Gregory's were guests of Arabi during their stay in Cairo. Like the Blunts they too believed that Egypt should be for the Egyptians and were against any invasion by the English. Arabi asked Blunt to go to London to explain the real situation and to endeavour to instil "peace and 
goodwill". He arrived in March 1882. He discovered that the Rothschilds among other investors of Europe were eager to invade Egypt.

In April 1882, an English fleet was ordered to Alexandria. Colonel Arabi and his men could easily have taken advantage of this situation and sank the ships but Arabi followed Mohammedan law of "not firing the first shot in war" (Blunt 1922). Like Fingal in The Poems of Ossian they only fought to defend (Macpherson 1996). At the same time, the Sultan wanted again to replace Tewfik with Halim. His choice was supported by Menotti Garibaldi who had got together volunteers to aid Arabi from May onwards (Blunt 1922). Arabi had sought support through a petition of his people for the return of Halim as Khedive (Landau 2015) who promoted Arabi's uprising (Andrew Jams McGregor 2006). In June 1882, Arabi turned down a monetary offer by Rothschild of four thousand pounds sterling annually until his demise to leave Egypt permanently. It was through lies in the press, exposed by William Blunt, that the English eventually found a reason to bomb Alexandria in July (Blunt 1922). Straight after Alexandria was bombed, the Sultan once more proposed that Tewik Pasha be replaced by Halim Pasha who, as ruler, would stop further bloodshed and satisfy everyone. The Sultan's proposal was rejected by the British government and was told not bother with such proposals (Baring 1908). By September, after the Egyptians fought the British Empire at Tel-el-Keber, they surrendered. Bad press in England demanded the death sentence for Arabi while Muhammad Abdu had been exiled for six years in 1882. Residing in Beirut for eight years, Abdu eventually became the Grand Mufti in Cairo (Blunt 1922). The powerful letter entitled "Arabi and his household", published in The Times on September 23, 1882, was written by Lady Augusta Gregory, and was her first published work. The following is an excerpt:

"Arabi is a good man and his aims are honest. I know it and you know it, but we dare not say it. A lady may say what she likes but a man is called unpatriotic who ventures to say a word that is good of a man England is determined to crush; it may injure us if we speaks as we think." (Bobotis 2007)

Lady Gregory's letter to "The Times" changed the minds of the English in their demand for the death sentence, having been swayed by misinformation. Indeed, it saved Arabi's life resulting in his being exiled to Ceylon instead of being hanged. It was later published as a pamphlet. Blunt paid part of Arabi's legal fees. (Blunt 1922). In a letter to his wife, William Gregory describes the events in Egypt as a result of England's bellicose stance, betraying his disgust at the slaughter, destruction and homelessness which resulted from the English government following the ill-advised advice of their resident diplomats in Egypt. (Gregory 2004). The Government had ignored Blunt's plea for peace and honest reporting of events. In his epic poem dedicated to Egypt entitled "The Wind and the Whirlwind": 
"...Alas for Liberty, alas for Egypt!

What chance was yours in this ignoble strife? Scorned and betrayed, dishonoured and rejected....

To conquer freedom with no drop of blood. This was your crime....." (Blunt 1922)

In December 1887, Panayiotis Panas published "The Death of Cuchullin" in Athens (Panas 1887). It was published shortly after the "Bloody Sunday" demonstrations in London held on November 13, 1887 by the Social Democratic Federation, the Socialist League and the Irish National League protesting against the the imprisonment of W. O'Brian, an Irish M.P., and the Tory Government's policies on the Irish and the economy (Wikipedia n.d.). One of the members of the Socialist League was William Morris with whom Wilfred Blunt was with with when the demonstration broke out. Blunt stated that the Irish people were confronted with "the same unscrupulous gang of financiers, property holders, mortgage companies and speculators as Egypt" (Longford 1979).

In 1888, Blunt took up the cause of Home Rule in Ireland for the Irish when he was arrested and imprisoned in Galway and Dublin (Longford 1979). In 1887, Panas translated "The Death of Cuchullin" published in "Evdomas" in Athens, which relates to the very first Ossianic imitation by Byron in 1850 in which Calmar and Orla sought help from Cuchullin (Panas 1887). Cuchullin symbolises the death of any hope of the Democratic Eastern Federation as Western monarchy had invaded the zone. In 1902, Augusta Gregory translated the Irish myths from the Cuchullain Cycle including, "Cuchullain of Muirtheme". After translating Celtic myths she claimed she had "done something for the dignity of Ireland. The reviews showed that the enemy [England] could no longer scoff at Irish literature and its want of idealism." (Boisseau 2004)

Five years later, Blunt's play "Fand", written in verse, was based on the Cuchullin Cycle. It was performed at the Abbey Theatre, founded by Lady Gregory, in Dublin:

"O pitiful Cuchulain! What fool's fate is thine

Thou mirror of our nation, our sun's self which did shine

Like daylight on the world, and drawing all to thee

How is thy pride departed: the fair witchery

Of the high hero's courage and thy manly face

Which was all Ireland's glory

Alban's sore disgrace

Beloving and beloved." (Blunt 1914)

In conclusion, dates recorded in a moment in time when the Great Powers had the ability to bring peace in the area but failed to do so coincide with a translation of The Poems of Ossian. This poetry also coincided with Western diplomatic machinations of the Great Powers, which succeeded in preventing unity through the Democratic Eastern Federation by British 
Imperialism. Similarly in Ireland this poetry was used to resurrect their freedom from oppression through the noble and just examples of Ossianic Warriors. If Halim Pasha had been installed as the rightful heir to the Khediveship in Egypt, there is no doubt he would have given his support to those adherents who had saved his life in 1866. Close colleagues of Panas, the main translator of The Poems of Ossian and leader of the Democratic Eastern Federation, they all sought to instil brotherhood, peace and harmony in federative states in the zone. Instead the vast indigenous people of different creeds underwent disunity, dispossession of land and deracination plus gruesome wars, which still persist, as a result of Imperialism. The gagging of The Poems of Ossian because of the "forgery issue" makes no sense if this poetry was used in translation to further a peaceful political movement which endeavoured to encourage Hellenism as a means of educating the people, while at the same time exposing the machinations of British Imperialism. After a stranglehold on translations of The Poems of Ossian for more than a century, the clamp, therefore, should be removed so that the value of this Celtic poetry, be it Irish or Scottish, can be reassessed and its worthiness reinstated.

\section{References}

Anonymous (1884) The Egyptian difficulty and the first step out of it. London: PS King \& Son, Parliamentary Agency.

Abduh M (2007) Three important autograph manuscripts, together with a good collection of his printed writings and reference works. Retrieved from http://bit.ly/2fWiGAT. [Accessed 14 May 2016].

Baring E (1908) Modern Egypt. New York: Macmillan.

Swanton Belloc L (1841) Chefs-d'oeuvre poétiques de Thomas Moore: avec une traduction des poésies satyriques et burlesques de Moore, une Notice sur la vie et les oeuvres du meme auteur, par D. O'Sullivan [Poetic works by Thomas Moore, with a translation of satiric and burlesque poems by Moore: A notice on the life and the works of the same author by D. O'Sullivan]. Paris: Gosselin.

Berman N (2004) Impossible missions? German economic, military and humanitarian efforts in Africa. Lincoln: University of Nebraska Press.

Blunt WS (1922) Secret history of the English occupation of Egypt being a personal narrative events. London: General Books

Blunt WS (1914) Poetical works complete edition. London: Macmillan and co.

Bobotis A (2007) From Egypt to Ireland: lady Augusta Gregory and cross cultural nationalism in Victorian Ireland. Romanticism and Victorianism on the Net 48. Retrieved from http://bit.ly/2fzNaJ0. [Accessed 21 February 2016].

Botsseau RJ (2004) The women of Abbey Theatre 1897-1925. PhD Diss, University of Maryland. Retrieved from http://bit.ly/2eWUf2F [Accessed 29 November 2015].

Bouvier J (1967) Les Rothschild [The Rothschild] Paris: Fayard.

Byron Lord (1919) The works of Lord Byron 5 vols. $2^{\text {nd }}$ ed. Paris: Gaulon.

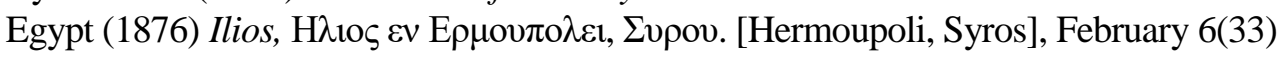

Clifford B (1984) The Life and poems of Thomas Moore (Ireland's National Poet). London, Belfast and Cork: Athol Books.

Elsie R (2012) Albanian literature: A short history. New York: Palgrave Macmillan. 
Flourens G (1868) La question d'Orient et l'insurrection crétoise [The Eastern question and the Cretan uprising]. Paris: Dentu.

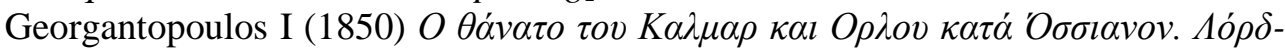
Bv́pwv [The death of Calmar and Orla by Ossian: by Lord Byron]. Athens: Evterpe.

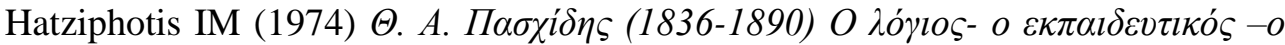

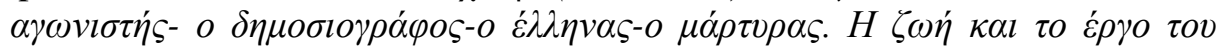

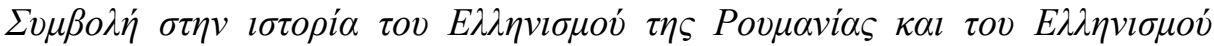

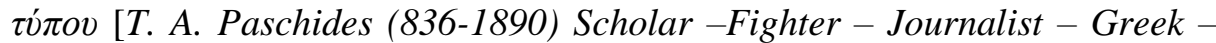
Martyr: His life and Teacher his work: symbol of the History of Hellenism in the Rumanian and Greek Press]. Athens: Kritikon Philon.

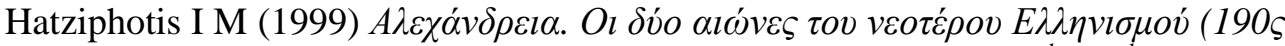
- 20ós) [Alexandria: Two Centuries of Modern Hellenism: $19^{\text {th }}-20^{\text {th }}$ century]. Athens: Ellinika Grammata.

Hill P (2015) The first Arabic translations of enlightenment literature: the Damietta Circle of the 1800s and 1810s. Intellectual History Review 25(2): 209-233.

Van Hook L (trans) (1986) Isocrates Nicocles I. London: Loeb Classical Library Heinemann.

Kedourie E (1997) Afghani and 'Abdu: An Essay on Religious Unbelief and Political Activism in Modern Islam. London: Routledge Library Editions: Islam. Frank Cass \& Co. Ltd.

Kippis A (1781) The new annual register of general repository of history, politics and literature. Retrieved from http://bit.ly/2dXYfTX. [Accessed 15 May 2016].

Konomos D (1953) A A $\alpha v \tau \alpha$. Tv $\pi \alpha \dot{\lambda} \delta$ So [The Complete Works of Julius Typaldos] Athens: Pigis.

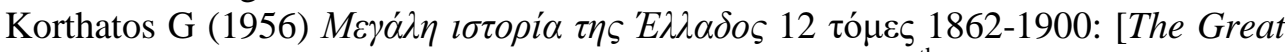
History of Greece, 12 volumes 1862-1900]. Athens: $20^{\text {th }}$ century.

Koukkou H E (2001) Ioannis A. Kapodistrias The European diplomat and statesman of the $19^{\text {th }}$ century Roxandra S. Stourdza A famous woman of her time. Athens, translated by Ekaterini Ghikas: The Society for the Study of Greek History.

Kudelin A (2009) Muhammad Abdu's letter to Leo Tolstoy (History of RussianArabic Cultural Dialogue in the Beginning of the $20^{\text {th }}$ century). Manuscripts Orientalia: vol. 16: 41-49 Retrived from http://bit.ly/2fXR1xe. [Accessed 15 May 2016].

Lake JW (1822) A biographical and critical sketch of Thomas Moore, Esq., comprising anecdotes of ancient minstrelsy, illustrated of the Irish Melodies. The works of Thomas Moore, Esq. Leipsig: Ernest Fleischer.

Landau JM (2015) Middle Eastern themes: Papers in history and politics. New York: Routledge. Retrieved from http://bit.ly/11znCzD. [Accessed 12 November 2015].

Longford E (1979) A pilgrimage of passion: The life of Wilfred Scawen Blunt. London: Weidenfeld and Nicolson.

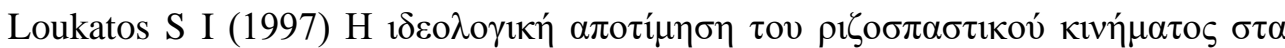

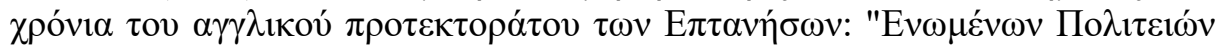

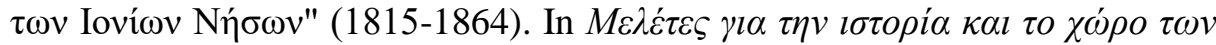

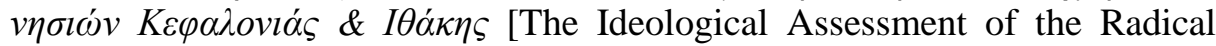
Movement in the years under the English Protectorate of the Seven Islands: The United Republic of the Ionian Islands (1815-1864)] Ilias Beriatos, editor Studies in the History and the Area of the Islands of Kephalonia and Ithaca, 103-125. Argostoli: The Kephalonian and Ithaca Association. 


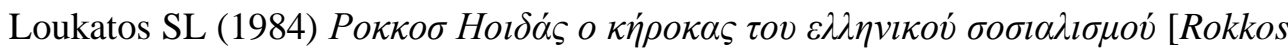
Hoidas: The advocate of Greek Socialism]. Athens: The Kephalonian and Ithacan Guild of Pireus.

MacGregor A J (2006) A military history of modern Egypt from the Ottoman conquest to the Ramadan war. USA: Praeger Security International.

Macpherson James (1762) Fingal, an ancient epic poem in six books: together with several other poems composed by Ossian, the son of Fingal: translated from the Galic Language by James Macpherson. London: T Becket and PA De Hondt.

Macpherson J (1996) The poems of Ossian and related works: with an introduction by $F$ Stafford. Edinburgh. Howard Gaskill, editor. Edinburgh: Edinburgh University Press.

Mathieu G (1966) Les idées politiques d'Isocrate: $2^{\text {nd }}$ edition [The political ideas of Isocrates: $2^{\text {nd }}$ edition]. Paris: Les Belles Lettres.

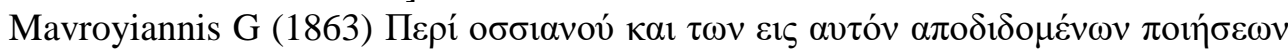
[Ossian and the Poems Attributed to Him]. Chrysalis 1(17): 417-420, 25-531.

Mitko T, In Wikipedia. Retrieved from http://bit.ly/2fcOFsC. [Accessed 12 April 2016].

Moore T (1839) The works of Lord Byron: with his letters and jourals, and his life. London: Murray

Moore T (1857) "Imitation of Ossian" The Celt, Dublin and New York.

Moraitinis, Pierre (1877) La Grèce Telle qu'elle est [Greece at it is]. Paris : Firmin Didot. Second Edition: Athens: Dionysios N. Karavia, 1987.

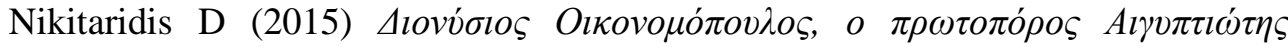

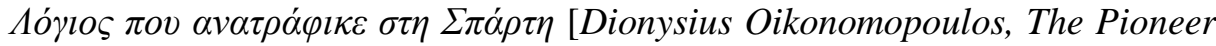
Egyptian schlar from Sparta]. Retrieved from http://bit.ly/2gfOh1J. [Accessed 24 October 2015].

O'Donnell KA (2014a) Nineteenth-Century Cycladic Warriors: Celtic Heroes. In Studies on Mediterranean Culture and History: from the Middle Ages through the Early Modern Period, Steven M. Oberhelman, editor: 165-172. Athens: Athens Institute for Education and Research (ATINER).

O'Donnell KA (2014b) How Twentieth Century Greek Scholars Influenced the Works of Nineteenth Century Greek Translators of "The Poems of Ossian" by James Macpherson. Athens Journal of Philology 1(4): 273-284.

Pashko V Revolvy. Retrieved from http://bit.ly/2fzUXX1. [Accessed 12 April 2016].

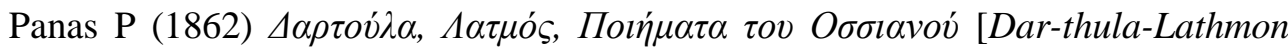
Poems of Ossian]. Kephalonia, British Protectorate: Kephallinia.

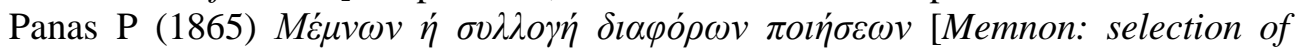
different poems]. Alexandria: Nile Press.

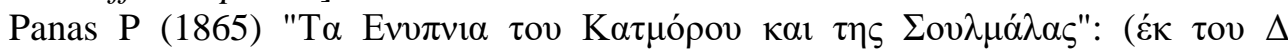

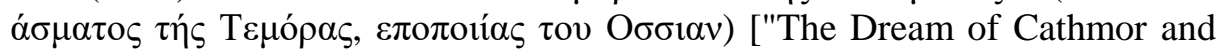
Sulmalla" from Temora Book IV]. Memnon, 36-41. Alexandrai: Nile Press.

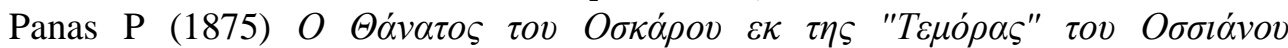

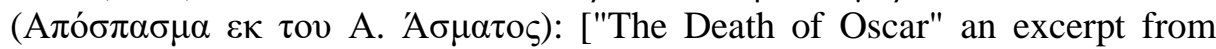
Temora Book I]. E $\xi \dot{\varepsilon} \gamma \varepsilon \rho \sigma \iota \varsigma, 24,22$ /3. Athens.

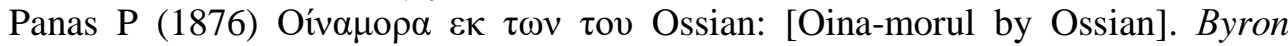
volume B: $120-3$.

Panas P (1877) Extract from Scene elleniche by Angelo Brofferio (1866) translator: The Denial of Patriotism. The Cave of Arakinthos: George Byron and George Varnakiotis'. Trans. Athens: Telegraph.

Panas P (1883) Disraeli Effendi: Hours of Idleness, 29-32 Athens: Enosis. 


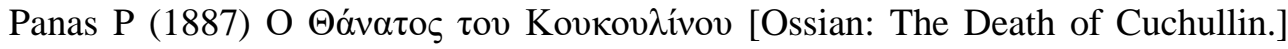
Evdoma 4s: Athens.

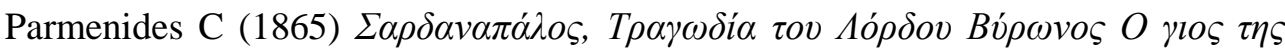

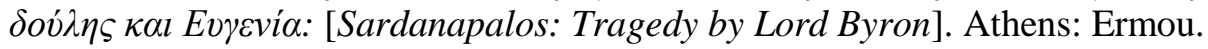

Paulin PM (1830) Oeuvres complètes de Lord Byron, avec notes et commentaires comprenant ses mémoires publiés par Thomas Moore, Tome Quatrième [Complete Works of Lord Byron, Notes and Commentaries comprising Memoirs published by Thomas Moore Volume 4] : Scientific editor: Thomas Moore (1779-1852). Paris: Dondey-Dupré.

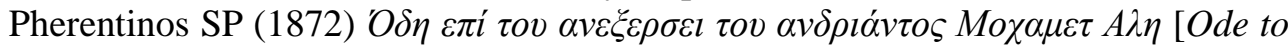
the erecting of the statue of Mohammad Ali]. Alexandria: Cleoptra.

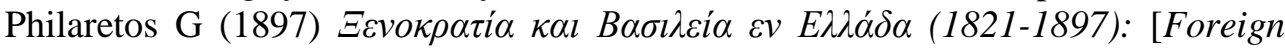
Government and Monarchy in Greece (1821-1897)]. Athens: S. Kousoulinos.

Ravanis GD (1982) Byron in Cefalonia H Cosmetato transator: Athens: Cefalonia: Corgialenis Foundation Historical and Cultural Museum.

Redgrave G (1891) A history of water-colour painting in England. http://bit.ly/ 2gfKi5j. [Accessed 15 May 2016]

Seaton-Watson RW (1935) Disraeli, Gladstone \& the Eastern Question. London: Macmillan.

Stafford F (1988) The sublime savage James Macpherson and The poems of ossian. Edinburgh: Edinburgh University Press.

Stavrianos LS (2000) The Balkans since 1453: with a new introduction by Traian Stoianovich. London: Hurst \& Co.

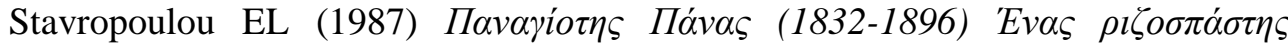

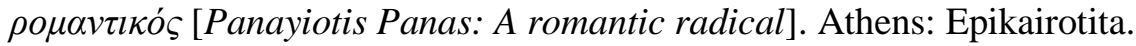

The Gospels and Psalms translated into Arabic by Mozarabs $(946 ; 889)$ Retrieved from http://bit.ly/1i0Qji8 [Accessed 15 May 2016]

Thomas D, Mallett A (eds) (2011) Christian-Muslim relations. A bibliographical history Vol. 3 (1050-1200). Leiden-Boston: Brill.

Thomson D (1979) England in the nineteenth century. Harmondsworth: Penguin.

Todorov Varban N (1995) Greek Federalism during the Nineteenth Century: (Ideas and Projects). New York: East European Quarterly, Boulder Distributed by Columbia University Press.

Trevelyan G M (1944) British history in the nineteenth century and after: (17821919). London: Longmans Green and Co.

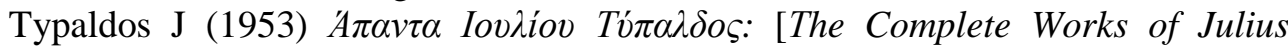
Typaldos]. D. Conomos (Ed). Athens: Pigis.

Typaldos J (1956) The Portrait of Lord Beaconsfield (Disraeli). Eptanisiaka Philla (October): 8.

Van Tieghem P (1917) Ossian en France, Tome Premier et Second [Ossian in France, volumes 1 and 2]. Paris: F. Rieder \& Cie.

Velestinlis R (2002) Revolutionary Scripts, Revolutionary Proclamation, Human Rights, the Constitution, Thourios. Vasilis K. Zervoulakos (trans) Dimitrios Karaberopoulos (ed). Athens: Scientific Society of Studies Pheres-VelestinoRhigas.

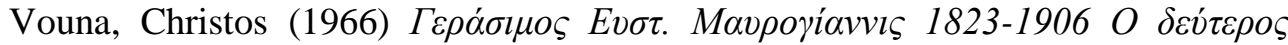

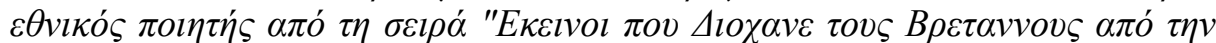

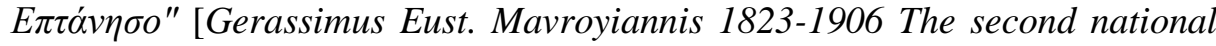
poet from the series: those who drove out the British from the Seven Islands]. Athens: Manakou-Anagnostopoulou

Wikipedia. Bloody Sunday. Retrieved from http://bit.ly/2gfI8T5. 
